\title{
Contemporary UK wage floors and the calculation of a living wage
}

\author{
Donald Hirsch \\ Centre for Research in Social Policy, \\ Loughborough University, Loughborough, UK
}

\begin{abstract}
Purpose - The purpose of this paper is to describe how the voluntary living wage (LW) in the UK is set. It examines how this calculation relates to contemporary approaches to setting wage floors, both in relation to their goal of supporting adequate living standards and in relation to the place of wage floors in the labour mark.

Design/methodology/approach - The paper examines how compulsory and voluntary wage floors are being determined, in the UK and in particular the role of public consensus in contributing to the calculation and adoption of a LW. It then reflects on the future sustainability of a system of wage floors in which the concept of the LW plays a significant role.

Findings - The central finding is that widespread support for wages delivering socially acceptable minimum living standards has transformed the context in which low pay is being addressed in the UK. The LW idea has stimulated more decisive efforts to do so; however, if a compulsory version of a LW were to reach a level shown to be harming jobs, this could seriously undermine such efforts. Moreover, the extent to which adequate wages are compatible with high employment levels can also be influenced by state support for households, especially tax credits and Universal Credit.

Originality/value - The paper clarifies how the setting of the UK LW contributes to objectives related both to living standards and to labour markets, and critically addresses some key issues raised.
\end{abstract}

Keywords Minimum wage, Living wage, Minimum income, Living standards

Paper type General review

\section{Introduction}

The central idea behind a living wage (LW) is that it should provide workers with enough income to live at a level considered sufficient in terms of contemporary norms and values. This immediately distinguishes it from a minimum wage, which refers to a statutory threshold that employers are required to pay, regardless of the basis on which its level is set. However, these concepts start to overlap where minimum wages seek in some explicit way to support adequate living standards, and in particular where the term "LW" is used to campaign for or to make claims about a compulsory minimum. The introduction in 2016 of the UK's "National Living Wage" (NLW), a compulsory rate for workers over 25, aiming to improve workers' living standards yet not calculated with reference to living costs, has partially merged policy debates on LWs and minimum wages that had previously been largely separate.

This paper describes current approaches to wage floors in the UK, the methods by which they are set and their distinctive and overlapping objectives. It then goes on to consider how living and minimum wages might develop in the UK over the next few years, and how they

(C) Donald Hirsch. Published by Emerald Publishing Limited. This article is published under the Creative Commons Attribution (CC BY 4.0) licence. Anyone may reproduce, distribute, translate and create derivative works of this article (for both commercial and non-commercial purposes), subject to full attribution to the original publication and authors. The full terms of this licence may be seen at: http://creativecommons.org/licences/by/4.0/legalcode. 
ER

39,6

816

relate to other policies. In doing so, the paper critically addresses on the one hand specific aspects of making a LW calculation, and on the other, more widely, the role that wage floors seeking to maintain living standards can play. It points to important ways in which the calculation and role of wage floors are connected.

The paper focusses on the UK, which provides a distinctive case in which explicit efforts to formulate public consensus both in researching minimum living standards and in giving stakeholders a role in approving the LW method have helped create a national concept of a LW level. This feature has strengthened the interaction between an ethically approved voluntary LW and a statutorily imposed minimum.

\section{Setting wage floors in the UK: current and recent practices}

In broad terms, there have been three distinct methods employed for setting wage floors over the past two decades in the UK (Prowse and Fells, 2016). The National Minimum Wage (NMW), introduced in 1999, seeks to outlaw exploitatively low pay, by setting a compulsory minimum at the highest rate that will not significantly damage labour demand. The voluntary LW used by the Living Wage Foundation to accredit "Living Wage Employers" is based on a wage rate considered adequate for a minimum acceptable standard of living. The NLW, introduced by the Government in 2016, is an enhanced compulsory minimum wage rate for over-25s, intended by 2020 to converge with and remain at 60 per cent of median pay.

The NMW is set annually on the recommendation of the Low Pay Commission (LPC) according to a simple principle in its terms of reference: "The aim of the LPC is to recommend levels for the minimum wage rates that will help as many low-paid workers as possible without any significant adverse impact on employment or the economy" (Low Pay Commission, 2017a). This implies that the NMW should be as high as possible without reducing employment levels or producing other undesirable economic side-effects, particularly an increase in general inflation. Despite having some selective price impacts and hence affecting relative prices (Wadsworth, 2007), the NMW does not affect overall pay bills nearly enough to cause significant concern about cost-push inflation across the economy (Metcalf, 2008, p. 32). The LPC's mission can thus be seen almost entirely in terms of identifying a wage that meets a single condition: the highest rate that will not significantly reduce the number of jobs. While this is in principle a technical matter, the inclusion of trade union and employer representatives as well as independent economists on the Commission reflects the high political sensitivity of where the level should be set, under conditions of highly imperfect knowledge about what level would reduce the number of jobs. The LPC has commissioned over 140 studies on the NMW since it was introduced in 1999 and found that it has had "little adverse effect on employment" (Low Pay Commission, 2016b, p. xvi; Metcalf, 2008). This reflects extensive research on minimum wage effects in the USA suggesting largely benign impacts overall (Schmitt, 2013; Hirsch and Valadez, 2017). Yet however much research takes place, the LPC ironically has a brief for which success entails continuing uncertainty, since allowing the NMW to rise to a level that significantly harms jobs would bring more knowledge but represent a policy failure. This goes a long way towards explaining why the LPC has tended to adopt a "cautious" approach to increases in the NMW (Bain Review, 2014, p. 40; Prowse and Fells, 2016).

Most importantly for the discussion of LWs, the LPC thus focusses on labour market effects, and any consideration of what wage is adequate to live on lies beyond its brief. The setting of the LW, in contrast, starts from the perspective that, for most household types, the NMW is insufficient to produce what society regards as an adequate standard of living, even in most households whose adults work full time (Hirsch, 2015a, pp. 21-22). The Living Wage Foundation accredits LW Employers who pay all workers at least the LW, which is independently calculated with reference to living costs, using the method described in the 
following section. In asking employers to commit to the LW, the Foundation and local Calculation of a campaigners are setting an ethical standard, to which good employers should aspire, living wage rather than basing the wage rate on affordability.

The announcement of the new NLW in 2015 by the then Chancellor, George Osborne (HM Treasury, 2015), was in practice a move to expand the ambitions of the NMW, yet in its motives, branding and presentation drew inspiration from the LW. A year earlier, a review of the NMW carried out by an independent commission led by the LPC's first chair (Bain Review, 2014) had concluded that its brief needed to be widened, from that of effectively a "minimum pay commission" (Prowse and Fells, 2016, p. 146: italics in original, describing LPC's focus on NMW), focussing on eliminating extreme low pay, to address low pay more broadly: the NMW has not had a sufficient "ripple up" effect to address the UK's low pay culture. The new NLW adopts the general approach recommended by Bain to seek to reduce the number of people who have low pay relative to the median. Bain had suggested requiring the LPC to chart a path towards a NMW of 60 per cent of median pay, subject to an assessment of its economic feasibility. Osborne went further by making an unconditional commitment to bring compulsory pay to 60 per cent of median earnings within five years, albeit only for workers over 25 , under the banner of the NLW, a policy confirmed by the Conservative Party (2017) in the 2017 General Election.

The use of the term NLW and the willingness to make a political commitment to a particular rate not contingent on labour market consequences revealed the importance to the government of being seen to address living standards, influenced by the political traction gained by the LW movement. Osborne's slogan that "Britain needs a pay rise" (HM Treasury, 2015) also recognised how the declining adequacy of wages since the recession needed to be taken into account, rather than considering a statutory minimum only on the basis of labour demand. Under this policy, minimum wages for over-25s are set to rise from 52.5 to 60 per cent of median earnings for over-25s between 2015 and 2020 (Low Pay Commission 2016a, p. 71). While not directly calculated with reference to living standards, this substantial pay rise, to be followed by the preserving of a rate relative to the median, will more systematically allow low-paid workers to benefit from economic growth. It is forecast to triple the number of workers whose pay is at the statutory minimum, from 1 to 3 million, with potentially another 3 million benefitting from ripple effects (Low Pay Commission, 2016b, pp. 65-66). This very decisively addresses the Bain criticism of the NMW that it only addressed very low pay rather than the low pay culture generally.

\section{Calculating the LW rate - underlying issues and the UK approach}

Of the three wage floors described above, the LW is the one whose appropriate level is the most complex. This is because the objective of setting wage floors as "the highest level that will not reduce labour demand" (NMW) or as a fixed percentage of median pay (NLW) are precise economic statements about pay levels, but a calculation of what is "enough to provide workers with a minimum acceptable living standard" (LW) can be approached in many different ways.

Ideas relating to what wage rate allows workers and their dependents to live at an acceptable level date back to medieval and ancient thinkers such as Plato and Thomas Aquinas (Anker, 2011; Stabile, 2008; Hirsch and Valadez, 2017). Laissez-faire classical economic theorists believed that allowing labour markets to act freely would result in reasonable wages (Hirsch and Valadez, 2017, pp. 4-6), whereas nineteenth century reformers such as Oldroyd (1894), John Ryan (1912) and J.A. Hobson (Brailsford et al, 1926) concluded that intervention was needed to rebalance the unequal market power that led to the sweatshops of the industrial revolution. However, both interventionists and laissez-faire advocates agreed that wages should do more than allow workers to survive, but also allow them to have the necessities required to live in dignity commensurate with contemporary society. The father of 
ER

39,6

818

classical economics, Adam Smith, expressed this clearly (aptly using language appropriate to the eighteenth rather than the twenty-first century):

By necessaries I understand, not only the commodities which are indispensibly necessary for the support of life, but whatever the custom of the country renders it indecent for creditable people, even of the lowest order, to be without (Smith, 1776, p. 479).

A direct application of this principle to wage-setting came in the landmark 1907 Harvester case in Australia, which ruled that wages should not just be enough to ensure survival but must cover "the normal needs of an average employee, regarded as a human being in a civilised community"; this became the basis of an Australian minimum wage system that remains the most generous in the world (see Hirsch and Valadez, 2017, p. 10).

The ideal of a worker being able to reach a living standard appropriate for the time and place where he or she lives survives to inform modern LW movements, but has been difficult to operationalise in a consistent way (Anker, 2011; Brenner, 2002). Conceptually, thinkers about poverty lines have distinguished between well-being based on a "welfarist" approach, focussing purely on a living standard relative to others in one's society, and a "non-welfarist" concept of having absolute "capabilities" within the context of one's contemporary environment (Ravaillon and Chen, 2011). However, in the practice of measurement, this distinction has proved less important than finding a valid way of determining the threshold of an acceptable living standard (Brenner, 2002, pp. 6-7). Many calculations have started with scientific assessments of the cost of meeting basic material needs such as pricing a minimum food basket, but the underlying challenge is how to extend this to assess a living standard appropriate for contemporary society in a specific place.

A common approach has been to start with the cost of buying material basics, and deduce additional costs based on what proportion of low income households' expenditure they are observed to comprise. This method has been commonly used both in the global South (e.g. in the Asia Floor Wage, Anker, 2011), and in many calculations of LWs in the USA (see Hirsch and Valadez, 2017, p. 29; Ciscal, 2002; Economic Policy Institute, 2015) as well as New Zealand (King, 2016; King and Waldegrave, 2012). In some contexts, such as the effort to achieve adequate pay for garment workers across Asian countries, this can be helpful in producing an easy to calculate formula to provide cross-national consistency. Yet it is problematic because it ignores the fact that the proportion of spending devoted to basic material essentials differs in countries at different levels of development (Anker, 2011). Moreover, since households with tight budget constraints are likely to have higher unmet needs in non-subsistence areas of their budget than in buying the essentials for survival, the observed ratio of total spending to expenditure on material essentials provides an unreliable guide to total needs (Hirsch and Valadez, 2017).

A different approach is to use budget standards (compiling lists of necessary items) to produce a fuller, more direct account of all the items that comprise a minimum household budget (Deeming, 2011). Some methods of compiling these lists are largely expert-based, using scientific approaches to specifying what is required to meet different categories of need (Bradshaw, 1993), sometimes following a rigorous theoretical framework (Goedemé et al., 2015). Others, such as the Minimum Income Standard, described below, are based mainly on what members of the public consider to be a minimum.

Budget standards work best where the objective is to measure a standard appropriate for one country without worrying about international comparability, since it allows a minimum to be defined in that country's own terms. This is illustrated in the development of a single widely accepted LW calculation in the UK, drawing on two aspects of public acceptability. The first is that the budget standards used to calculate minimum household spending requirements result from "consensual" research, based on views of members of the public. The second aspect is that the application of this living standards calculation to the LW is the product of consensus-building among stakeholders. 
The method used to produce the UK's Minimum Income Standard (Bradshaw et al., 2008; Davis et al., 2015) is a refinement of 25 years of developing budget standards, and became the dominant method used from 2008 when expertise developed by the University of York's Family Budget Unit (Bradshaw, 1993) was combined with that of Loughborough University's Centre for Research In Social Policy (CRSP) (Middleton et al., 1994), which had been developing a technique for consulting the general public. The result is a primarily "consensual" method involving decisions by groups of randomly recruited members of the public, which is regularly updated with new research. MIS involves a succession of detailed deliberations among small groups to build up a picture of how a particular family type would reach a minimum, defined as follows:

A minimum standard of living in the UK today includes, but is more than just, food, clothes and shelter. It is about having the opportunities and choices that you need in order to be able to participate in society (Davis et al., 2015).

The MIS method also involves experts in informing groups, for example on whether food meets healthy nutritional standards, but the judgements about what an acceptable living standard entails rests with the public. Socio-economically mixed groups of six to ten individuals each spends several hours identifying which household items are required to meet the definition in each part of the budget of an individual demographically similar to themselves; subsequent groups check back on and amend these decisions, and also identify how individual needs are combined into households. Researchers price the goods and services identified and draw up budgets for a wide range of family types.

The principle that budgets drawn up by members of the public can represent social consensus about what comprises a minimum standard was been vital in the adoption of a LW calculation based on MIS by the Living Wage Commission. This independent collection of employer, trade union and academic representatives was established by the accrediting body, the Living Wage Foundation, in 2016 to supervise a national method for setting LW rates for London and for the rest of the country. A national figure, it said in its first report, should "accurately reflect the views and experiences of ordinary people [...] about what is required to fully participate in society, and how social norms and needs change over time" (Living Wage Commission, 2016, p. 5). A single new method based on MIS was therefore adopted to replace separate methodologies for London and outside, the London calculation having drawn on an older, expert-based method (GLA Economics, 2015) and the outside London one by CRSP, on the basis of MIS (Hirsch and Moore, 2011).

Under the authority of the Commission, the new calculation of the LW is carried out by the Resolution Foundation (D'Arcy and Finch, 2016b), and can be summarised as follows. First, the costed MIS budgets are used to calculate most costs for different types of household. Second, some costs which are hard to standardise because they differ across areas are based on a range of data, including average amounts paid for social rents, for council tax and for childcare. Private rents, which are assumed to be the minimum cost for working age adults without children, who rarely have access to social housing, are based on the average lower quartile rent across areas (to allow people some choice over housing without suggesting that the quality available for an average rent is the "minimum"). Next, for each household type, an hourly wage rate is calculated that would be sufficient to produce the required budget, after deducting tax and adding on any benefits and tax credits to which one would be entitled, assuming that the adult or adults in the household work full time. Then, a weighted average of these hourly wage requirements is calculated according to the representation of different household types in the population. This produces an overall LW calculation (separately for London and for the rest of the UK), which is applied, unless it would involve an increase since the previous year of more than 3 per cent above the Consumer Prices Index, in which case its increase is limited to that amount.
Calculation of a living wage 
ER

39,6

820

In authorising this method, the Living Wage Commission has selected an agreed approach not just to the basis for describing a living standard, but also for three other issues that frequently arise when setting a LW: how to deal with local variations in costs, how to represent multiple households requiring different wage rates to reach a common living standard and how to uprate a LW over time. Again, having an independent body to adjudicate these issues helps to produce acceptance for a single national approach.

The issue of local variations has been particularly important in the USA, where various calculators adapt local LWs to geographical cost differences such as housing (Economic Policy Institute, 2015; MIT, 2017; Ciscal, 2002). However, this can create a confusion of different rates, sometimes applied in the same area, and the averaging method used in the UK, described above, is a conscious compromise to produce a widely known and accepted figure for campaigning purposes.

A harder issue to resolve concerns the extent to which a LW covers the needs of different types of household. No one hourly wage rate will produce the same living standard for all households, since households differ greatly by the number of hours' wages that come in and by the number of household members that these earnings, combined in some cases with benefits and tax credits, have to provide for (Bennett, 2014). One approach is to ensure that wages are enough to provide for a family, for example with two parents and two children, accepting that it is unrealistic for a wage to provide for the largest families, but equally that for a single person, such a LW may be considerably in excess of what they need. LWs are based on a family of four In Canada and New Zealand, with a justification for the latter as being that this is the size of family needed for population "replacement" (King, 2016; Hirsch and Valadez, 2017, p. 33). An alternative approach argues that while employers should ensure that a worker can earn enough to support themselves, it is more the role for family benefits to provide for dependents, and that therefore a LW should be based on meeting the needs of a single person. This has been the approach in Ireland, influenced by the level at which a LW is thought to be realistic (Collins, 2014).

The choice for the UK of a middle way between a family and a single person's LW, based on a weighted average for households of different composition, was taken by the Living Wage Commission because of its desire that the LW should cover a "broad and representative mix of family types" (Living Wage Commission, 2016, p. 5). This was based on a finding from a stakeholder consultation by the body advising the Commission: that employers and employees would find a LW less credible if it was calculated based only on the needs of one group of workers (D'Arcy and Finch, 2016a, p. 25).

The same review argued, also on the basis of consultations, that the LW calculations should be based only on households whose adults worked full time (D'Arcy and Finch, 2016a, p. 27). It is recognised that for many working households, this does not reflect reality. However, it is not realistic to think that employers will pay a wage that provides enough to live on regardless of how many hours someone works. For families such as lone parents and those with disabilities who may find it harder to manage a full-time job, the state has a particularly strong role in helping to top up part-time wages. A strong argument for a LW is that wages should at least allow the opportunity to reach a given standard of living through full-time work.

The final issue that affects any calculation of a LW is that it has to be set at a realistic, stable level. That is to say, there is no point setting a LW that few employers feel that they can afford to adopt, or that they will find it impossible to maintain as its level changes over time. These are difficult conditions to meet, at the same time as keeping the integrity of a wage based on maintaining living standards, under changing conditions. Both of the pre-2016 methods of setting LWs in the UK had stabilisers built in, but the context in which these were applied risked compromising the link with living standards. The UK LW calculated by Loughborough University (Hirsch and Moore, 2011) put a limit on the amount that the wage could increase in any one year, to the increase in average earnings plus 2 per cent. 
Where the cap was applied, a "reference rate" based on actual living costs continued to produce a benchmark to which the applied rate should converge where conditions allowed. However, in the four years following the launch of this method in 2011, the stagnation of real wages combined with cuts in tax credit entitlements (which meant that substantially higher wages were needed by families to maintain a given living standard) resulted in the cap always being applied, and by 2015 the reference rate was over $£ 1$ an hour above the applied rate (Hirsch, 2015b). In the case of the London LW, half the calculation was always calculated with reference to median income rather than living costs. Moreover, for the half of the calculation that did consider household living costs, in about half of household cases annual increases were determined by the level of the NMW rather than changes in living costs themselves, since the formula did not allow any household's wage in this calculation to fall below the NMW plus 15 per cent (GLA 2015). Thus both inside and outside London, stabilisers in the formula weakened considerably the link between changes in the applied LW and changes in living costs.

The LW calculation introduced in 2016 under the Living Wage Commission helps address this difficulty, both in the way that it is constructed and in the way that it is governed (D'Arcy and Finch, 2016a, b). In its construction the calculation is linked entirely to living costs rather than (as in the GLA calculation) relating it partly to median income or the NMW, but this living cost calculation is designed it to be more stable than the preceding UK LW calculated by Loughborough University. The weighting method used in the new system has been refined to give relatively less weight to families with children and less weight among such families to those with very young children requiring childcare. LW requirements for families with children are made highly volatile in the UK by the existence of steeply means-tested in-work benefits, since a small increase in costs requires a much larger increase in the wage, to make up for the loss of tax credits as wages rise. Additional volatility for families with young children has been caused by steep increases in childcare costs combined with a changing framework of public subsidy to help with these costs. In the present system, only a third of the UK-wide weighted calculation (34 per cent) is based on families with children, down from nearly half (48 per cent) in the previous version, and a calculation based on model families all of whom were assumed to have at least one child under five has been replaced by a population-reflecting set of examples, in which only about a third of families have at least one child of that age (D'Arcy and Finch, 2016b, p. 6; Hirsch, 2015b, p. 10). Despite this smaller exposure to potentially the greatest source of fluctuation, the cap on annual increases of CPI plus 3 per cent protects against any sudden rise.

None of this is a guarantee against the previous experience of unfavourable economic circumstances triggering a permanent cap that causes the link between the LW and living costs to be weakened. However, a critical new feature lies in the way that the LW calculation is governed. The Living Wage Commission $(2016$, p. 8) has said that it will continue to review the economic environment and the operation of the LW. Although it is committed to maintaining a system under which people on low pay with Living Wage Employers have their pay increased to reflect changes in living costs, it may decide to phase in changes or adapt the system if circumstances require this. Having an independent body with the authority to do so is a means of ensuring that the LW remains both credible and sustainable.

\section{Is the LW idea sustainable in setting wage floors in the UK?}

This paper has shown that the compulsory NLW and the voluntary LW are different animals, but with a common ambition of promoting improved living standards among the UK"s worst paid workers. The NLW is a means to tackle wage inequalities among workers over-25s more ambitiously (by being higher) and more systematically (by being pegged to median pay) than the NMW has done, and continues to do for under-25s. The LW, unlike the $\mathrm{NLW}$, is calculated directly with reference to living standards, with the involvement of
Calculation of a living wage 
ER

39,6

822

the general public in defining contemporary minimum needs contributing to its public credibility. This has helped promote the LW concept, and has clearly influenced the government's adoption of the NLW, as evidenced by the adoption in 2015 of the term "LW" to characterise a compulsory minimum rate.

An interesting parallel is the prominent use of the term "LW" by President Franklin Roosevelt to describe the first federal minimum wage that he introduced into the USA in 1933. Yet in recent years, the federal minimum has declined in value: since the 1960s, it has fallen by a quarter in real terms, to less than half what it would be had it risen with average productivity (Hirsch and Valadez 2017, p. 14). What was introduced as a "LW" is now associated with living in poverty.

In seeking to make a genuine LW more sustainable, policy makers and campaigners seek to maintain a difficult balance between its credibility in relation to living standards and realism in terms of employers' ability to pay it. In the UK, the establishment of an independent commission to keep the method for setting the LW under review is intended to add to the authority of a wage-setting system that may need to be adjusted from time to time in order to keep these factors in balance.

For both the LW and the NLW, the affordability issue will not go away, and will be influenced by two crucial factors other than living costs themselves: the level of labour demand, which will determine what wage floor is affordable and does not create unemployment, and the level of state support for low income working households, which will influence what wage is sufficient to deliver minimum living standards.

On the issue of labour demand, the LPC continues to advise on the relationship between compulsory wage floors (the NMW and, for over-25s, the NLW) and employment levels. In the case of the NLW, however, its brief is presently limited to advising on the very narrow issue of how to stage the introduction of a politically prescribed relative pay level: 60 per cent of median pay by 2020 . The Commission has warned of considerable uncertainty among employers, especially in certain sectors such as social care, about the potential impact on the labour market of future increases, but has so far chosen to recommend a straight-line trajectory to the politically determined 2020 rate (Low Pay Commission, 2016b). In the event that it finds, in future, that there has been a negative effect on the number of jobs, ministers would have to weigh the benefits of fulfilling a political pledge aiming to raise workers' living standards against the economic costs of reduced employment, including for those on low incomes who became unemployed as a consequence.

In such an event, another option would be to make relatively greater use of means-tested support for low-income working families, notably Universal Credit (UC), which is replacing tax credits as the main state top-up based on post-tax income and family composition. Delivering the 2015 Budget, George Osborne explicitly sought to shift the balance more in the direction of wages rather than such tax-funded transfers in improving the living standards of working families (HM Treasury, 2015). Yet his proposed cuts in tax credits (although not in UC) had to be abandoned because they produced losses that would have greatly outweighed the very modest net gains that working families would get from a higher wage floor (Hirsch, 2015c). Conversely, improvements in the level of UC support, or a raising of the "work allowance" above which UC starts being withdrawn with rising income, would reduce the wage needed to produce an acceptable living standard. In the long term, a sustainable strategy for ensuring that wages are at a level high enough to provide decent living standards must necessarily consider what contribution the state should make to supporting families, in light of what employer contribution is compatible with high employment levels.

The terms of this debate have been altered by the introduction of a compulsory wage floor that calls itself a "LW" and is not set purely with regard to what wage level labour demand can support without harming employment or the economy. The voluntary LW has been taken up by employers who think they can afford to pay it; the compulsory rate applies 
to all. In early 2017, the April 2020 rate for the NLW was forecast to be about $£ 8.75$ by Low Pay Commission (2017b, p. 19), 35 per cent higher than the NMW five years earlier. Such a transformational increase in a compulsory minimum will provide perhaps the biggest research laboratory ever seen for how employers respond to a large hike in minimum wages. The results are likely to inform policy, both on wages and on other support for low income working households, for many years to come.
Calculation of a living wage

\section{References}

Anker, R. (2011), Estimating A Living Wage: A Methodological Review, International Labour Organisation, Geneva.

Bain Review (2014), "More than a minimum: the Resolution Foundation review of the future of the national minimum wage", final report, Resolution Foundation, London.

Bennett, F. (2014), “The 'living wage', low pay and in work poverty: rethinking the relationships", Critical Social Policy, Vol. 34 No. 1, pp. 46-65.

Bradshaw, J. (Ed.) (1993), Budget Standards for the United Kingdom, Avebury, Aldershot.

Bradshaw, J., Middleton, S., Davis, A., Oldfield, N., Smith, N., Cusworth, L. and Williams, J. (2008), A Minimum Income Standard for Britain: What People Think, Joseph Rowntree Foundation, York.

Brailsford, H., Hobson, J., Creech Jones, A. and Wise, E. (1926), The Living Wage, Independent Labour Party, London.

Brenner, M. (2002), "Defining and measuring a global living wage: theoretical and conceptual issues", paper, conference Global Labor Standards and Living Wage, University of MassachusettsAmherst, April, pp. 19-20.

Ciscal, D. (2002), “The determination of living wage”, in Figart, D. (Ed.), Living Wage Movements. Global Perspectives, Routledge, New York, NY, pp. 51-66.

Collins, M. (2014), “A living wage for Ireland: some considerations and initial estimates", Nevin Economic Research Institute, Dublin, available at: www.conservatives.com/manifesto (accessed 28 May 2017).

Conservative Party (2017), "Forward together: the Conservative Manifesto 2017", Conservative Party, London.

D'Arcy, C. and Finch, D. (2016a), Making the Living Wage - The Resolution Foundation Review of the Living Wage, Resolution Foundation, London.

D'Arcy, C. and Finch, D. (2016b), Calculating a Living Wage for London and the Rest of the UK, Resolution Foundation, London.

Davis, A., Hirsch, D., Padley, M. and Marshall, L. (2015), How Much is Enough? Reaching Social Consensus on Minimum Household Needs, Centre for Research in Social Policy, Loughborough.

Deeming, C. (2011), "Determining minimum standards of living and household budgets methodological issues", Journal of Sociolgy, Vol. 47 No. 1, pp. 17-34.

Economic Policy Institute (2015), "The Economic Policy Institute's 2015 family budget calculator, technical documentation”, Working Paper No. 299, Economic Policy Institute, Washington, DC.

GLA Economics (2015), A Fairer London: The 2015 Living Wage in London, GLA, London.

Goedemé, T., Storms, B., Stockman, S., Penne, T. and Van den Bosch, K. (2015), “Towards cross-country comparable reference budgets in Europe: first results of a concerted effort", European Journal of Social Security, Vol. 17 No. 1, pp. 3-30.

HM Treasury (2015), "Summer budget 2015”, HM Treasury, London, available at: www.gov.uk/ government/topical-events/budget-july-2015 (accessed 2 August 2015).

Hirsch, D. (2015a), A Minimum Income Standard for the UK in 2015, Joseph Rowntree Foundation, York.

Hirsch, D. (2015b), "Uprating the UK Living Wage in 2015", working paper, Centre for Research in Social Policy, Loughborough. 
ER

39,6

Hirsch, D. (2015c), Will the 2015 Summer Budget Improve Living Standards in 2020?, Joseph Rowntree Foundation, York.

Hirsch, D. and Moore, R. (2011), The Living Wage in the United Kingdom - Building on Success, Living Wage Foundation, London.

Hirsch, D. and Valadez, L. (2017), The Living Wage, Agenda Publishing, Newcastle upon Tyne.

King, P. (2016), "Setting the New Zealand living wage: complexities and practicalities", Labour \& Industry: A Journal of The Social and Economic Relations of Work, Vol. 26 No. 1, pp. 8-23.

King, P. and Waldegrave, C. (2012), "Report of an investigation into defining a living wage for New Zealand”, Report for the Living Wage Campaign, Family Centre Social Policy Research, Lower Hutt.

Living Wage Commission (2016), Closing the Gap: Final Report of the Living Wage Commission, Living Wage Foundation, London.

Low Pay Commission (2016a), "National minimum wage”, Low Pay Commission Report Spring 2016, Low Pay Commission, London.

Low Pay Commission (2016b), "National minimum wage”, Low Pay Commission Report Autumn 2016, Low Pay Commission, London.

Low Pay Commission (2017a), "Terms of reference", available at: www.gov.uk/government/ organisations/low-pay-commission/about/terms-of-reference (accessed 23 February 2017).

Low Pay Commission (2017b), A Rising Floor: The Latest Evidence on the National Living Wage and Youth Rates of the Minimum Wage Low Pay Commission April 2017, Low Pay Commission, London.

Metcalf, D. (2008), "Why has the British national minimum wage had little or no impact on employment?", Journal of Industrial Relations, Vol. 50 No. 3, pp. 489-512.

Middleton, S., Ashworth, K. and Walker, R. (1994), Family Fortunes: Pressures on Parents and Children in the 1990s, CPAG, London.

MIT (2017), "Living wage calculator", available at: http:/livingwage.mit.edu/articles/19-new-datacalculating-the-living-wage-for-u-s-states-counties-and-metro-areas (accessed 31 May 2017).

Oldroyd, M. (1894), A Living Wage, McCorquodale \& Co., Leeds.

Prowse, P. and Fells, R. (2016), "The living wage - policy and practice", Industrial Relations Journal, Vol. 47 No. 2, pp. 144-162.

Ravaillon, M. and Chen, S. (2011), "Weakly relative poverty", The Review of Economics and Statistics, Vol. 93 No. 4, pp. $1251-1261$.

Ryan, J. (1912), A Living Wage, its Ethical and Economic Aspects, Macmillan, London.

Schmitt, J. (2013), "Why does the minimum wage have no discernible effect on employment?", working paper, Center for Economic and Policy Research.

Smith, A. (1776), "An enquiry into the nature and causes of the wealth of nations", available at: www.ifaarchive.com/pdf/smith_-_an_inquiry_into_the_nature_and_causes_of_the_wealth_of_ nations $\% 5 \mathrm{~B} 1 \% 5 \mathrm{D}$.pdf

Stabile, D. (2008), The Living Wage: Lessons from the History of Economic Thought, Edward Elgar, Cheltenham.

Wadsworth, J. (2007), "Did the minimum wage change consumption patterns? Report to low pay commission”, Working Paper No. 1517, Centre for Economic Performance.

\section{Corresponding author}

Donald Hirsch can be contacted at: L.J.Jones@Lboro.ac.uk

For instructions on how to order reprints of this article, please visit our website:

www.emeraldgrouppublishing.com/licensing/reprints.htm

Or contact us for further details: permissions@emeraldinsight.com 